\title{
Maanyan Language Internal Innovation
}

\author{
Siti Jamzaroh ${ }^{1 *}$, Eka Suryatin ${ }^{2}$, Achril Zalmansyah ${ }^{3}$, Zainal Abidin ${ }^{4}$ \\ ${ }^{1,2}$ Balai Bahasa Provinsi Kalimantan Selatan \\ ${ }^{3}$ Kantor Bahasa Provinsi Lampung \\ ${ }^{4}$ Balai Bahasa Provinsi Riau \\ *Corresponding author.Email: asiti.jamzaroh@kemdikbud.go.id
}

\begin{abstract}
The aims of this reasearch are (1) to describe phonological innovations (internal) in the Maanyan language that contains Batapah Village (BMB), Malungai Village (BMM), Ipu Mea Village (BMI), and Warukin Village (BMW); (2) to describe the phonological changes or shifts that occur between the three dialects (Dusun Pepas dialek, Paju Epat dialect, and Dusun Witu dialect). The research method used is a comparison method and a bottom up reconstruction method. The results found were 1) vowels $/ *_{\mathrm{u}} /, / *_{\mathrm{i} /}$ and $/ *_{\mathrm{e}} /$ experienced retention in Maanyan, while vowels /*a/ and /*ay/ experienced sound changes $\rightarrow / \mathrm{e} / /$ ey/ ; 2) sound changes that occur are sound attenuation $\left(/ * \mathrm{~b} /, / *_{\mathrm{v}} / \rightarrow / \mathrm{w} /\right)$, sound attenuation, sound amplification $(/ * 1 / \rightarrow / \mathrm{d} /$ ), sound addition, merging (protophoneme $* \mathrm{~b}$, $* \mathrm{v}$, and protophoneme $/ * \mathrm{~d} /, / * \mathrm{t} /, * 1 \rightarrow 1 \mathrm{BM}$; protophoneme $/ * \mathrm{D} /, / * \mathrm{~d} /, / * \mathrm{r} / \rightarrow / \mathrm{r} / \mathrm{BM})$ and sound replacement $(/ * \mathrm{c} / \rightarrow / \mathrm{s} /)$
\end{abstract}

Keywords: innovation, retention, and reconstruction method

\section{INTRODUCTION}

\subsection{The Background Problem}

Maanyan language is classified into Dayak language as well as Ngaju (Kahayan), Lawangan, Samihin, Dusun Witu, Dusun Deyah, Taboyan, Sampit, Tunjung, Bakumpai, and others. The term Dayak is generally used to refer to the indigenous people who live on the island of Borneo [1]. However, according to Darmansyah [2], German scholars often use this term to refer to natives of Kalimantan who are not Muslims. (p. 2).

Like all languages in Kalimantan, the Maanyan language is a spoken language. Therefore the Maanyan language has no alphabet. Dahl [3] stated that the written in Maanyan language only came into existence after German missionaries arrived after World War I. Cense A. A and Unlenbeck [4] stated that "Maanyan is spoken in the region of which Tamiang Layang is the centre and which extend roughly between the Barito and its tributary the Karau in the west, and beyond the Gunung Meratus in the East". Maanyan is spoken in the region of which Tamiang Layang is the centre and which extends roughly between the Barito and its tributary the Karau in the west, and beyond the Gunung Meratus in the East. Cense and Uhlenbeck [4] statement is clear, spontaneous and has not been supported by data in the field. This is because they do not mention which villages or regions were the speakers of the Maanyan language (p. 38).

Speakers of the Maanyan language live in a fairly large area. Darmansyah [2] stated that the Maanyan-speaking area in the west occupies the area between the Barito River, in the east occupies the Meratus mountains, and Tamiang Layang is the centre of the Maanyan-speaking area (p.1).

\subsection{Previous Studies}

The results of the literature search were obtained from Rinah [5], entitled "The Kinship Relations between Malagasy and Maanyan languages". In her study, Rinah[5] said that the results of the lexicostatistics study obtained a close relationship between BMs (Malagasy language) and BM (Maanyan language) as of $48.3 \%$. This shows that Malagasy belongs to the subfamily of related languages (West Polynesian Malay). The Malagasy language, which has been suspected to have a close kinship with the Maanyan language, is not the case.

Internal Innovation Research of Maanyan Language by using four observation point locations, namely Batapah Village, Timpah District, District of Kapuas, which is bordered to District of North Barito; Malungai Village, Kecamatan Mount Timpang, District of North Barito, Central Kalimantan; The two observation 
points represent the Dusun Pepas dialect; Ipu Mea Village, Kecamatan Paku, District of East Barito represents the Paju Epat dialect; and Warukin Village, Kecamatan Tantaringin, District of Tabalong, South Kalimantan which is bordered by District of South Barito represents the dialect of Dusun Witu. The data was obtained from the Swadesh Vocabulary of South Kalimantan 2012, and Language Mapping in Central Kalimantan (not recorded, 2008). Both data were taken at the same time. Only observation point in Ipu Mea Village, Kecamatan Paku, District of East Barito which is additional data to represent the Paju dialect.

PAN's Internal Innovation Research on the Maanyan Language, was carried out within the framework of a comparative historical linguistic study, although the Swadesh vocabulary data was still in the scope of one language, namely the Maanyan language.

The problems in this research are (1) are there any phonological innovations found in the Maanyan language, (2) how do sound changes occur? While the research objectives are (1) to describe the phonological (internal) innovations found in the four observation points of Batapah Village (BMB). Malungai Village (BMM), Ipu Mea Village (BMI), and Warukin Village (MMW); and 2) to describe the phonological changes or shifts that occur between the four dialects.

\section{METHOD}

According to Lehman [6], the methods of historical linguistic research include the comparative method, the internal reconstruction method, and the glottochronology method. He further stated that to interpret data of historical linguistic studies, there are two very important methods, namely the method of comparison and the method of internal reconstruction. The method of comparison (will be described in chapter V) is illustrated on a sample of selected words from French, Italian, Spanish, and Portuguese (p. 7--8).

\subsection{The Comparative Method}

$\begin{array}{lllll}\text { Perancis } & \text { Italia } & \text { Spanyol } & \text { Portugis } & \text { Inggris } \\ \text { huit } & \text { otto } & \text { ocho } & \text { Oito } & \text { fight } \\ \text { lait } & \text { latte } & \text { leche } & \text { Leite } & \text { milk } \\ \text { fait } & \text { fatto } & \text { hecho } & \text { feito } & \text { fact }\end{array}$

The comparison method is done by comparing the consonants and vowels contained in the first, second, third, and so on lines in each language. In the first line, it still looks difficult to decipher from common sources. When data is added, we can decipher it from Latin and explain the development of differences of the languages from one another. Basic conclusions and observations of the language change.

\subsection{Internal Reconstruction}

The internal reconstruction method is used to find the protophonemes of the languages being compared. This reconstruction is also called the bottom-up method 'from the bottom up', namely from the innovation of phonemes found in modern languages that are raised to PAN protophonemes, while on the other side, if the PAN protophonemes are searched for their modern forms in the languages being compared, it is called the top-down method 'from above. down'. In this study, this research uses the top-down method, by utilizing the protophoneme list contained in the English Finderlist of Reconstruction in Austronesian Language. (Post Brandsteiner) by Wurm, S.A. dan Wilson [7].

\subsection{Glottochronology}

This method is a quantitative approach and is a follow-up method after lexicostatistics which is intended to find out when the separated languages are compared.

Based on the three methods above, this research is focusing only on the two methods that are the method of comparison and the method of internal reconstruction to process and analyze Maanyan language data.

\section{FRAMEWORK OF THEORY}

\subsection{Proto-Austronesian}

Fernandez [8] stated that PAN has four vowel phonemes, namely, $*_{\mathrm{i}},{ }^{*} \mathrm{u},{ }^{*} \mathrm{a}$, and $*$ ě. Those vowels can appear in any position except $*$ ě which does not occupy the final open position. In addition to vowels, PAN also has six diphthongs, namely, *ay, *aw, *uy, *ey, *ěw and *iw. All diphthongs only occupy the final position. PAN consonants consist of 25 consonants, namely *p, *b, *t, *T, d, *D, *k, *g, *c, *dj, *m, *n, *n, *n̆, ${ }^{*} \mathrm{~s},{ }^{*} \mathrm{~S},{ }^{*} \mathrm{z}, * \mathrm{Z},{ }^{*} \mathrm{~h}, * 1, * \mathrm{r},{ }^{*} \mathrm{R},{ }^{*} \mathrm{q},{ }^{*} \mathrm{y}$, and ${ }^{*} \mathrm{w}$. The consonants $* \mathrm{Z}, * \mathrm{~T}, \mathrm{z}$, and $* \mathrm{n}$ are not found in the final position; while $*_{j}$ is not found at the beginning of the word. The consonant groups that appear are nasal consonants that only appear in the position between vowels (pp. 149-151). 


\subsection{Maanyan Phonemes}

Darmansyah [2] found that the Maanyan language has four vowels, namely $/ \mathrm{i} /, / \mathrm{u} /, / \mathrm{a} /$, and /e/. The vowel /e/ is usually pronounced as $[\varepsilon]$. Due to the influence of the Banjarese language, the Bakumpai language has vowels [Ә] or e pepet, although not many are found. The Maanyan diphthongs include /ay/ /aw/, /uy/, and / $/ \varepsilon y /$. Maanyan consonants also have 18 consonants, namely /p/, /b/, /d/, /t/, /j//k/,/g/, /?/, /h/, /m/, / n/, $/ \mathrm{y} /, / \mathrm{n} /, / \mathrm{r} /, / 1 /, / \mathrm{j} /, / \mathrm{y} /, / \mathrm{g} /, / \mathrm{s} /$ and /w/. Maanyan language does not have the phonemes $/ \mathrm{c} /$ and $/ \mathrm{z} /$, therefore words absorbed in Banjar or Indonesian will be pronounced /s/. Meanwhile, the phoneme /z/ which is an absorption phoneme in Arabic is also not found in the Maanyan language (p.33).

\subsection{Types of Sound Change}

Crowley [9] mentions that there are types of sound changes that occur in each language development when compared to ProtoAustronesian. The sound changes include 1) attenuation of sound (lenisi), that is the change in sound from a strong sound to a weak sound, including reduction of consonant clusters, apheresis, apocopy, syncopy, haplology, and compression; 2) addition of sounds of anapticsis, epenthesis, prosthesis; 3) metathesis; 4) fusion (merging); 5) The loosening process; 6) vocal splitting; 7) assimilation; and 8) dissimilation.

\section{DISCUSSION}

\subsection{Phonological Innovation of PAN in Maanyan Language}

A phonological reconstruction of the Maanyan language was carried out on all possible PAN phonemes in Maanyan. As previously mentioned, PAN has four vowel phonemes, namely, $*_{\mathrm{i}}$, ${ }^{*} \mathrm{u}$, $*$ a, and *ě. These vowels can appear in any position, except vowel $*$ ě.

As for consonants, not all glosses can be found in their original form in the English Finderlist of Reconstruction in Austronesian Language by Wurm and Wilson[7], so not all vocabulary or glosses can be reconstructed.

Based on observations, the nasal consonants $/ \mathrm{m} /$ and $/ \mathrm{n} /$, have not changed, from the original form they were lowered into the Maanyan language which means that they are experiencing retention. Other consonants, such as $/ \mathrm{k} /, / \mathrm{g} /, / \mathrm{h} /$ were not found enough evidence because of the constraints mentioned above.
The following is the result of tracing the PAN reflex in the Maanyan language.

\subsection{Vowel}

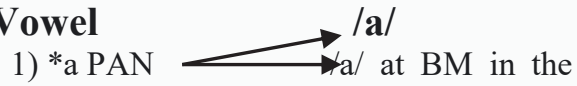

ultimate open position (-v), and a in the closed ultimate position (-v\#), penultima (\#v-, kv-). The following is the data found in the 200 basic Swadesh vocabulary compared.

\begin{tabular}{|c|c|c|c|c|c|}
\hline Gloss & PAN & BMW & BMB & BMM & BMI \\
\hline $\mathrm{ibu}$ & *ina & ?ineh & ineh & Ineh & ineh \\
\hline an & $*_{\text {ikan(a) }}$ & kenah & kenah & Kenah & kenah \\
\hline & *tu?a & matue & matueh & matueh & matu?eh \\
\hline nah & *tana? & $\tan \varepsilon ?$ & tane & $\tan \varepsilon$ & $\tan \varepsilon ?$ \\
\hline
\end{tabular}

In the example, the phoneme $/ * \mathrm{a} /$ remains $/ \mathrm{a} /$ in the BM in the first syllable, while the ultima position is closed, and in the open ultima position $/ * \mathrm{a} /$ changes to /e/ or and in the modern Maanyan language $(-\mathrm{k}-\mathrm{v}-\mathrm{k})$ position.

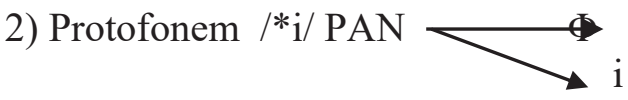

$\begin{array}{llllll}\text { Gloss } & \text { PAN } & \text { BMW } & \text { BMB } & \text { BMM } & \text { BMIP } \\ \text { ibu } & *_{\text {ina }} & \text { ?ineh } & \text { ineh ineh } & \text { ineh } \\ \text { ikan } & *_{\text {ikan(a) }} & \text { kenah } & \text { kenah } & \text { kenah } & \text { kenah } \\ \text { ular } & *_{\text {ipay }} & \text { hanipe } & \text { anipe } & \text { anipe } & \text { an dipe } \\ \text { benih } & * \text { binih } & \text { wini } & \text { paUn } & \text { wini } & \text { wini? } \\ & & & & \text { (pajkan) }\end{array}$

3) Protophonemes $/ * \mathrm{u} /$ and $/ * \mathrm{e} /$ are still retained or retention in Maanyan language (not discussed).

\subsubsection{Diphthongs ay, aj, uy, and ey \\ e.g 2 \\ Gloss PAN BMW BMB BMM BMI \\ ular *ipay hanipe anipe Anipe an dipe \\ mati *matay Matey mate: matey Matey matey \\ sungai *tunaj hunEy.hunəy huney Huney huney \\ telur *(h)antəluy anteluy ateloy Atelu ateluy}

In e.g (2) the protophoneme /*ay/, j changes to /e/, or in Maanyan; but some have changed to /ey/ or $/ y /$ the protophonemes /*uy/ or /*oy/ PAN seem to be preserved in the current Maanyan language. 


\subsubsection{Consonants}

4.1.3.1 Consonant/*b/ becomes /w/ BM

$\begin{array}{llllll}\text { Gloss } & \text { PAN } & \text { BMW } & \text { BMB } & \text { BMM } & \text { BMI } \\ \text { hidup *bəlum } & \begin{array}{l}\text { welu } \\ \mathrm{m}\end{array} & \text { welum } & \text { welum } & \text { welum } \\ \text { Perem *babina } & \begin{array}{l}\text { wawəy, } \\ \text { wawEy }\end{array} & \begin{array}{l}\text { wawe } \\ \text { ) wawey }\end{array} & \text { wawey } \\ \text { puan *bahi } & & & & \\ \text { benih *binih } & \text { wini } & \text { paUn } & \begin{array}{l}\text { wini } \\ \text { (pankan) }\end{array} & \text { wini? }\end{array}$

In the example above, it can be seen that $/ * \mathrm{~b} /$ PAN develops into $\mathrm{w}$ BM in its modern form, at positions $/{ }^{*} \mathrm{k}-/$ and $/-\mathrm{k}-/$, so the protophoneme $/ * \mathrm{~b} /$ in addition to being $/ \mathrm{b} /$, also developed into $/ \mathrm{w} /$ in modern BM.

\subsubsection{Consonant $/{ }^{*} v /$ PAN $\rightarrow$ becomes}

\begin{tabular}{|c|c|c|c|c|c|}
\hline \multicolumn{6}{|c|}{$/ w / B M$} \\
\hline Gloss & PAN & BMW & BMB & BMM & BMI \\
\hline buah & *vua & wua & wua? & wua & wuw \\
\hline bulan & $*$ vulan & wulan & Wulan & wulan & wulan \\
\hline baru & *va?uru & wa?u & wa?u & wa?u & wa?u: \\
\hline enar & *ba- & wu? & Wuah & bujur & wu+ah \\
\hline & nuvu & & & & \\
\hline tuh & *sovu & lawu & lawu? & lawU & lawu? \\
\hline & *yuvañ & han & han & han & han \\
\hline & & wuan & wuan & wan & wu+an \\
\hline
\end{tabular}

As in e.g 4.2.1 and 4.2.2 show the change in the protophoneme $/ *_{\mathrm{v}} /$ which evolved into $/ \mathrm{w} /$ in modern Maanyan. This happens in all positions, both $/ * \mathrm{k}-/, /-\mathrm{k}-/$, and /-k/ positions.

From e.g 4.2.1 and 4.2.2 show that the phoneme $/ \mathrm{w} /$ in Maanyan language is the result of a combination of the protophonemes $/ * \mathrm{~b} /$ and $/ * \mathrm{v} /$ PAN.

\subsubsection{Consonant $/ * d /, / D / \rightarrow / r / B M$}

$\begin{array}{llllll}\text { Gloss } & \text { PAN } & \text { BMW } & \text { BMB } & \text { BMM } & \text { BMI } \\ \text { rumput } & \text { *dikut } & \text { rikkut } & \text { rikut } & \text { rikut } & \text { rikut } \\ \text { ludah } & \text { *duDa } & \text { ?ifwey, rura? } & \text { ru?ra iwey } \\ & \text { q } & \text { rura? } & & & \\ \text { dua } & \text { *duva, } & \text { ruweh rueh } & \text { rueh } & \text { ru+eh } \\ & \text { *rua } & & & & \\ \text { daun } & \text { *Dawə } & \text { rawen rawen } & \text { rawe rawe }\end{array}$

\begin{tabular}{|c|c|c|c|c|c|}
\hline & $\mathrm{n}$ & & & $n$ & $\mathrm{n}$ \\
\hline dengar & *dener & reךei & $\begin{array}{l}\text { reney } \\
\text { (sanreney }\end{array}$ & rehey & reney \\
\hline busuk & $\begin{array}{l}{ }^{*} \text { buDu } \\
k\end{array}$ & buruk & buruk & buru? & buruk \\
\hline
\end{tabular}

The protophoneme consonants $/ * \mathrm{~d} /, / * \mathrm{D} /$ are found to be /r/ consonants in modern Maaanyan. As in the example above, the gloss of rumput become *dikkut $\rightarrow$ rikkut at the Warukin observation point, and rikkut at the other three points.

$$
\begin{aligned}
& \text { 4.1.3.4 Consonant } / *_{t} /, / *_{j-} / \rightarrow / r / B M \\
& \text { GLOS PAN BMW BM BM BMI } \\
& \text { S B M } \\
& \text { itu *itu(h) yiru Iru iru iru? } \\
& \text { hujan *hujan uran uran uran ura d }
\end{aligned}
$$

\begin{tabular}{|c|c|c|c|c|c|}
\hline 1.3.5 & $\begin{array}{r}\text { Consona } \\
\text { /l/ BM }\end{array}$ & $t / * 1$ & ${ }^{*} \mathbf{d}$ & $/ \mathbf{t} /$ & nd \\
\hline Gloss & PAN & BMW & $\mathrm{BMB}$ & BMM & BMI \\
\hline sedikit & *buDbuD & duhu & butit & butit & butit \\
\hline laut & *lawud & lawut & $\begin{array}{l}\text { laut } \\
\text { tahik }\end{array}$ & laut & a+ut \\
\hline lidah & *dilah & |cla & lela? & lela & ela? \\
\hline jauh & *alawi(dDj) & lawit & lawit & lawit & awit \\
\hline
\end{tabular}

Based on the description 4.1.3.4 and 4.1.3.5 can be concluded that the consonant $/ \mathrm{r} /$ in the Maanyan language is a combination of the protophonemes $/ * \mathrm{t} /$, and $/ * \mathrm{~d} / / *^{*} \mathrm{D} /$.from PAN.

The protophonem $/ * \mathrm{~d} /$, in all positions changes to a consonant $/ \mathrm{t} /$ in Maanyan.

\subsubsection{Consonant $/ * t /, / * l / \rightarrow / l / B M$ \\ Gloss PAN BMW BMB BMM BMI \\ lutut *[t]u'ud ?ulu? ulu? laleku?a ulu? alep alep $n$ alep \\ hidup *bəlum welum welum welum velum}

Based on the descriptions of 4.1.3.5 and 4.1.3.6 it can be concluded that the consonant $/ \mathrm{t} /$ in Maanyan is a combination of the protophonemes $/ * \mathrm{D} /, / * \mathrm{~d} /, / * \mathrm{t} /$, and /consonan $/ \mathrm{l} /$ is a combination of $/ * \mathrm{~d} /, / * \mathrm{D} /$, and $/ * 1 /$ 


$\begin{array}{llllll}\text { 4.1.3.7 } & \text { Consonant } / * c / s / & B M & \\ \text { Gloss } & \text { PAN } & \text { BMW } & \text { BMB } & \text { BMM } & \text { BMI } \\ \text { cacing }{ }^{*} \text { caciN } & \text { Sasin } & \text { sasin } & \text { sasin } & \text { sasin } \\ \text { cium }{ }^{*} \text { ciyum } & \text { Siyuk } & \text { siuk } & \text { siuk } & \text { si\&uk }\end{array}$

The protophoneme $/ * \mathrm{c} /$ that changes to $/ \mathrm{s} / \mathrm{BM}$ is found to be limited. So the Maanyan language does not have the consonant $/ \mathrm{c} /$.

$\begin{array}{llllll}\text { 4.1.3.8 } & \text { Consonant } / * l / & \rightarrow / d / B M & \\ \text { GlOSS } & \text { PAN } & \text { BMW } & \text { BMB } & \text { BMM } & \text { BMI } \\ \text { kulit } & * \text { kulit } & \text { kudit } & \text { kudit } & \text { kudlt } & \text { kudit } \\ & & \text {,?upak } & \text { (upak) } & & \\ \text { gali } & * \text { kali } & \text { tabuk kakat kadi } & \text { kadi: }\end{array}$

The protophoneme /*1/ which develops into /d/ indicates the strengthening of the sound of the language.

\subsection{Sound Change}

After being analyzed, it was found that there was evidence of sound changes that occurred in the Maanyan language seen from its relation to the PAN's protophoneme. Indeed, not all phoneme changes can be presented in this research do to the limitataion of data. However, this research also found that there is a significant change in sound when compared to the protophoneme of PAN. These changes are permanent (innovation) and some are secondary or sporadic. The following are the types of sound changes that occur.

\subsubsection{Sound Attenuation}

Sound attenuation occurs in some of the sounds that produce sounds in today's Maanyan language.

\subsubsection{Protophoneme /* b/ -> /w/, /v/ $\rightarrow$ /w/ BM \\ Gloss PAN BMW BMB BMM BMI \\ hidup bəlum welum welum welum welum \\ buah *vua wua wua? wua wuwa?}

Sound attenuation can also cause the loss of syllables or phonemes in either the front or the back of the word.

\subsubsection{Protophoneme /*k/ $\rightarrow / ? /, / \Phi /, / k /$ $B M$}

The protonphoneme $/ * \mathrm{k} /$ that disappears or becomes glottal is only sporadic. Supporting evidence or evidence of treeflex $/ * \mathrm{k} /$ in Maanyan language is found more in all positions.

\begin{tabular}{|c|c|c|c|c|c|}
\hline GLOSS & PAN & BMW & BMB & BMM & BMI \\
\hline kepala & *kuluk & ?ulu? & ulu? & Ulu & ulu? \\
\hline rumput & *dikut & rikkut & rikut & rikut & rikut \\
\hline *pandak & ?imbe: & imbe? & ime & $\mathrm{m} \sim \mathrm{bE} ?$ & *pandak \\
\hline \multicolumn{6}{|c|}{ 4.2.1.3 Disappearance in Front Position } \\
\hline Gloss & PAN & $\mathrm{BM}$ & BMB & BMM & BMI \\
\hline dorong & *t?uju & $\begin{array}{l}\text { W } \\
\text { juun }\end{array}$ & joroG & juUn & ju?un \\
\hline hidung & $\begin{array}{l}\eta \\
\text { *isusun }\end{array}$ & urun & urun & urUn & uru $=\eta$ \\
\hline kepala & *kuluk & ?ulu? & ulu? & Ulu & ulu? \\
\hline
\end{tabular}

At the above example, the nasal proto gloss form $/ *_{i}{ }^{*}$ isusuy/ was not inherited completely in Maanyan, but underwent a translation of /is/ and the consonant change from $/ \mathrm{s} /$ to $/ \mathrm{r} /$ in the current Maaanyan language (except in BMB locus).

\subsubsection{Immersion in Back Position Gloss PAN BMW BMB BMM BMI \\ baru *va?uru wa?u wa?u wa?u wa?u:}

Loss of sound also occurs at the end of the word, as in the new gloss which has the proto. /*va"uru/ form which was reduced to Maanyan to all dialects to /wa'u/.

\subsubsection{Sound Amplification}

Sound Reinforcement is also found in the Maanyan language although in limited quantities.

\subsubsection{Consonant $/ *_{i} /$ changes into consonant /d/ in Maanyan language}

Sound reinforcement only occurs in one protophoneme, namely the phoneme /*1/ which turns into $/ \mathrm{d} /$. It is called sound reinforcement because the protophoneme $/ * 1 /$ is a weak phoneme and the phoneme $/ \mathrm{d} /$ is a stronger phoneme (see Crowley [9]).

$\begin{array}{llllll}\text { Gloss } & \text { PAN } & \text { BMW } & \text { BMB } & \text { BMM } & \text { BMI } \\ \text { kulit } & \text { *kulit } & \text { kudit } & \text { kudit } & \text { kudlt } & \text { kudit } \\ & & \text { ?upak } & \text { (upak) } & & \end{array}$




$\begin{array}{lllll}\text { gali } & { }^{*} \text { kali } & \text { tabuk kakat kadi } & \text { kadi: } \\ \text { tali } & * \text { tali } & \text { tadi: tadi tadi } & \text { tadi: }\end{array}$

Sound reinforcement is followed by the addition of sounds, either in front, in the middle, behind or a combination of both.

\subsubsection{Sound Addition}

The addition of sound occurs because the current form has additional vowels and consonants when compared to the protophoneme form.

\subsubsection{Addition in Front}

\begin{tabular}{|c|c|c|c|c|}
\hline Gloss & PAN & BMW & BMB & BMM \\
\hline lihat & *unun & din:un & $\begin{array}{l}\text { dinun } \\
\text { (tantaw) }\end{array}$ & dinun \\
\hline lurus & *tu?lid & witu? & witu? & rata \\
\hline hitam & *hi(n)təm & ma?intem & maintem & nten \\
\hline malam & *maləm & $\begin{array}{l}\text { kamalem, } \\
\text { kamalEm }\end{array}$ & kamalem & \\
\hline reka & *erei & hErə? & here & e \\
\hline & *aran & naran & naran & naran \\
\hline
\end{tabular}

At the example above, it is shown that there are additional phonemes and syllables found in the modern Maanyan language. The addition of vowel or consonant phonemes is found in their gloss and names, and the addition of straight, black, and night syllables.

4.2.2.2 Addition in the Middle

Gloss PAN BMW BMB BMM BMI

makan *ka?ən kuman kuman kuman kuman

The insertion $/ \mathrm{um} /$ is added followed by a glottal loss between the vowels /a/ and / /. Its happened in this cases (limited data).

\subsubsection{Additions in Back}

Gloss PAN BMW BMB BMM BMI

ayah *?ama? amah ambah amah am bah

Seeing from the original form /*amah'/ which means 'father' in the modern Maanyan language, it gets an addition at the end to become /amah/, /ambah/, /amah/, and /ambah/ in its dialects. 4.2.2.4 Additions in Front and Back

The addition of sound can occur simultaneously in front of and behind the proton shape. Here is the data found as below.

Gloss PAN BMW BMB BMM BMI tajam *mata kumat kumat kumat kumat

There is an addition of the syllable $/ \mathrm{ku} /$ so that /*eye/ which means 'sharp' becomes kumat due to the loss of the vowel /a/ in the ultima position.

\subsubsection{Substitution}

Internal innovation is a substitution process from protophonemes to phonemes in Maanyan language. So it's no longer discussed in this section.

\section{Gloss PAN BMW BMB BMM BMI hujan *hujan uran uran uran ura $\mathrm{dn}$ F sempit *petpet hipit hipit hipit hipit \\ 4.2.4 Sound Merging} di

From description 4.2, it is known that some of $\mathrm{m}_{\text {the }}$ phonemes of the Maanyan language are the $K_{i}$ result of a fusion or combination of several phonemes. These phonemes include /r/, /w/, /e/, $\mathrm{h}$ and others. The following will be summarized for Đrreminding.

\subsubsection{Protophoneme $/ * b /, /{ }^{*} v /, / * w / \rightarrow$ /w/ BM

$\begin{array}{cllll}\text { Gloss PAN } & \text { BMW } & \text { BMB } & \text { BMM } & \text { BMI } \\ \text { buah *vua } & \text { wua } & \text { wua? } & \text { wua } & \text { wuwa? } \\ \text { bulu *bulu } & \text { wulu } & \text { wulu } & \text { wulu } & \text { wulu: } \\ \text { akar *wakat } & \text { wakat } & \text { wakat } & \text { wakat } & \text { wakad }\end{array}$

The example above is an example of merging or fusion which shows that the phoneme $/ \mathrm{w} /$ in Maanyan language is the result of fusion from the protophonemes $/ * \mathrm{v} /, /{ }^{*} \mathrm{~b} /$, and $/{ }^{*} \mathrm{w} /$. In addition to the phoneme $/ \mathrm{w} /$, another consonant is the phoneme $/ \mathrm{r} /$.

4.2.4.2 Protophoneme $/ * D /, / * d /, / * r-/ \rightarrow / r /$ $B M$

$\begin{array}{llllll}\text { Gloss } & \text { PAN } & \text { BMW } & \text { BMB } & \text { BMM } & \text { BMI } \\ \text { rumput } & \text { *dikut } & \text { rikkut } & \text { rikut } & \text { rikut } & \text { rikut } \\ \text { ludah } & \text { *duDaq } & \text { ?ifwey, } & \text { rura? } & \text { ru?ra } & \text { iwey } \\ \text { rura? } & & & \\ \text { dua } & \text { *duva } & \text { ruweh } & \text { rueh } & \text { rueh } & \text { ru+eh } \\ & \text { *rua } & & & & \\ \text { air } & \text { *ranu ranu } & \text { ranu? } & \text { Ranu } & \text { ranu }\end{array}$


In this example, it can be seen that the phoneme $/ \mathrm{r} /$ in the Maanyan language is a combination of the protophonemes $/ * \mathrm{~d} /, / * \mathrm{D} /$, and $/ * \mathrm{r} /$.

\subsubsection{Protophoneme $/ * d /, / * t /, / * l / \rightarrow / l /$} $B M$

$\begin{array}{llllll}\text { Gloss } & \text { PAN } & \text { BMW } & \text { BMB } & \text { BMM } & \text { BMI } \\ \text { lidah } & * \text { dilah } & \text { IEla } & \text { lela? } & \text { lela } & \text { lela } \\ \text { lutut } & *[\mathrm{t}] \mathrm{u} \text { 'ud } & \begin{array}{l}\text { ?ulu? } \\ \text { alep }\end{array} & \begin{array}{l}\text { ulu? } \\ \text { alep }\end{array} & \begin{array}{l}\text { ulu? } \\ \text { alep }\end{array} & \text { laleku?an } \\ \text { bulan } & * \text { vulan } & \begin{array}{l}\text { wulan } \\ \text { wulan }\end{array} & \text { wulan } & \text { wulan }\end{array}$

In the next example, it is known that the current Maanyan phoneme $/ 1 /$ is a combination of $/ * \mathrm{~d} /, / * \mathrm{t} /$, and $/ * 1 /$.

\section{SUMMARY}

Based on the description above, it can be concluded that not all data protophonemes were found to have developed in the Maanyan language. There are three points can be conculded as follows.

1. Internal Innovation/Phonology of the Maanyan language does not occur in all protophonemes, among the phonemes $/ * \mathrm{u} /$, $/ * \mathrm{i} /, / * \mathrm{~m} /, / \mathrm{n} /, / \mathrm{y} /$, and $/ \tilde{\mathrm{n}} /$ still reflected in the Maanyan language.

2. Sound changes that occur in the Maanyan language are sound attenuation, sound reinforcement, addition, replacement, and merging.

3. Some protophonemes cannot be found in the present form in Maanyan language, because reconstructed PAN not all words in Maanyan can be associated with PAN protophonemes in English Finderlist of Reconstructions in Austronesian Languages.

Furthermore, I would like to thank my friends who contributed to obtaining data on the Swadesh vocabulary of the Maanyan language, especially the mapping team of the Central Kalimantan Language Center, Mr. Yuliadi Rosga, so that this research would be useful for the study of the development of the Maanyan language in the future.

\section{REFERENCES}

[1] Hudson, A. B. (1976). The Barito Isolect of Borneo.

[2] Darmansyah. (1992). Fonologi Bahasa Maanyan. Proyek Penelitian Bahasa dan Sastra Indonesiadan Daerah Kalimantan Selatan Pusat Pembnaan dan Pengembangan Bahasa Departemen Pendidikan dan Kebudayaan.

[3] Dahl, O. C. (1951). Malgache et Maanyan: Une Comparison Linguistique. Egede Institute.

[4] Cense A. A dan Unlenbeck. (1958). Critical Survey of Studies on The Language of Borneo. Gravenhage: Martinus Nijhoff.

[5] Rinah, N. J. (2010). Hubungan Kekerabatan Bahasa Malagasy dan Bahasa Maanyan. Universitas Negeri Surakarta.

[6] Lehman, W. P. (1962). Historical Linguistics: an Introduction. Holt Rinehart and Winston.

[7] Wurm, S.A. dan Wilson, B. (1983). English Finderlist of Recontructions In Austronesian Languages. Departement of Linguistics Research School of Pasific Studies The Australian National University.

[8] Fernandez, I. Y. (1994). Relasi Historis Kekerabatan Bahasa Flores: Kajian Linguistik Historis Komparatif Terhadap Sembilan Bahasa di Flores. PT Nusa Indah.

[9] Crowley, T. (1997). An Introduction ti Historical Linguistics (Third Edit). Oxford University Press. 